\section{UCDNN}

LIBRARY
University of Connecticut OpenCommons@UConn

NERA Conference Proceedings 2008

Northeastern Educational Research Association

(NERA) Annual Conference

$10-23-2008$

\title{
Cognition and Student Learning Through the Arts
}

Steven A. Melnick

Pennsylvania State University, sam7@psu.edu

Judith T. Witmer

Pennsylvania State University - Harrisburg, JTWitmer@aol.com

Martha J. Strickland

Pennsylvania State University - Harrisburg, mjs51@psu.edu

Follow this and additional works at: https://opencommons.uconn.edu/nera_2008

Part of the Curriculum and Instruction Commons

\section{Recommended Citation}

Melnick, Steven A.; Witmer, Judith T.; and Strickland, Martha J., "Cognition and Student Learning Through the Arts" (2008). NERA Conference Proceedings 2008. 2.

https://opencommons.uconn.edu/nera_2008/2 
Cognition and Student Learning through the Arts

\author{
Steven A. Melnick, Ph.D. \\ Judith T. Witmer, Ed.D. \\ Martha J. Strickland, Ed.D. \\ Pennsylvania State University at Harrisburg
}

Paper presented at the annual meeting of the Northeastern Educational Research Association, Rocky Hill, CT, October 22-24, 2008. 


\title{
Cognition and Student Learning through the Arts
}

\begin{abstract}
An increasing number of recent research studies suggest connections between cognition, social and emotional development, and the arts. Some studies indicate that students in schools where the arts are an integral part of the academic program tend to do better in school than those students where that is not the case. This study examines home/school factors that contribute most to variance in student learning and achievement and the arts from over 8,000 students in grade 5. The findings suggest in-school arts programs may have less of an impact on student achievement than proposed by previous research.
\end{abstract}


For as long as humankind has been able to think logically, we have thought about thinking: What is it that enables us to learn and what is happening physiologically, psychologically, and educationally? As a modern society we have been trying for more than a hundred years to understand "how the brain works," and the renewed interest during the last thirty years in formalizing cognition has intrigued both practitioners and researchers who believe that there are positive effects on the academic achievement of students engaged in the arts. It has taken centuries for thinkers to uncover evidence of arts cognition, the "emotive" part of who we are. The objective of this research is to explore the relationships among school and home-based characteristics related to involvement in the arts and its impact on student learning.

\section{Background}

Plato and Aristotle both recognized the importance of emotion. Hobbes, Bacon, Descartes, Hume and others were intrigued by the cause of emotions. While William James viewed emotional states as aberrations and Freud wrote of their repression, only Jung developed a distinctive theory (Jarrett, 1993). Jarrett notes that while feelings and emotions historically have been viewed as the antithesis to reason, there is a growing understanding, mainly through the work of developmentalists, that humankind is more than only rational. This has particular significance for teaching, as each learner brings a myriad of cognitive, conative, and affective attitudes to the classroom. While always of interest to educators, the actual application of what is known about how children learn has been limited because of the lack of yet definitive research, particularly in the area of the effect of the arts on student academic success.

In the early history of education in the United States, educators varied in their views of 
arts education. Horace Mann in the late 1800s pushed to have visual arts and music in common schools, and in the early $20^{\text {th }}$ Century John Dewey commented that the imprint of the aesthetic is needed on any intellectual idea for that idea to be complete. Dewey identified and supported that there was a positive correlation between cognition and instruction in the arts; this had a strong effect on many curriculum decisions in many places at that time (Gullatt, 2008).

Circa 1950-80, most schools offered arts education for its own sake (not to enhance any other goal). In 1974 Elliot Eisner called for the evaluation of arts programs; this resulted in evidence suggesting that arts education positively affects aspects of living and learning beyond the intrinsic values of the arts themselves. Jarrett (1993) raised questions concerning the lack of educational theory addressing expressive feelings in teaching and learning.

In the 1990s some arts educators themselves began developing new programs and practices grounded in the idea that the arts were cognitive and that art study could have serious academic benefits, and they began integrating arts. Qualitative data noted that these programs "energized" teachers, leading to broader school change when teacher schedules were changed, parents became resources, teachers became leaders, and teaming ensued (Rabkin \& Redmond, 2006; Witmer, 1996; 1997a; 1997b).

\section{Cognition Studies as Applied to Education}

Cognition, or how the brain learns, is a field of study that has been gathering momentum since the 1980s, following a Congressional resolution in 1989 when President George H. W. Bush proclaimed the 1990s the "Decade of the Brain." Since then there has been an explosion of information on how the human brain works. Many of the new findings have changed medical practice, such as the understanding of mental illnesses and the drugs which control them.

Educational applications of these scientific findings are still relatively new. Scientific 
researchers, while acknowledging the potential for applying their findings to educational settings, are still cautious and advise educators to proceed carefully, paying particular attention to (1) well-established findings that validate what good educators have always done and (2) emerging findings that should lead educators to take a closer look at educational practice. These findings include the following: a) the brain changes physiologically as a result of experience, b) the environment determines to a large degree the cognitive ability of the brain; c) IQ is not fixed at birth; d) some abilities are acquired more easily during certain sensitive periods; and e) learning is strongly influenced by emotion (Wolfe \& Brandt, 1998).

Among the many research agencies who confirm this application is Educational Research Services whose finding is representative of most studies: when the basic principles of cognitive research are considered, “...it is clear that many current instructional approaches are compatible with our current understanding of how the human brain works" (Fischer \& Rose, 1998, p. 4). Wolfe (as cited in D'Arcangelo, 1998), responds to this, "Our challenge in education is to determine what makes an enriched classroom environment...the interaction of the student's mind with the materials and the simulations to make learning meaningful” (p. 22).

Cognitive research has taken the earlier conception of human development as a sequence of stages and revealed it as a complex, dynamic pattern of change with many properties. For example, Diamond and Hopson show that humans have a "new opportunity for relearning skills and reshaping networks that they missed in earlier cycles (Fischer \& Rose, 1998, p. 56).

Darby and Catterall (1994) credit cognitive psychologists George Miller, Herbert Simon, and Lev Vygotsky for breaking fresh ground in learning theory through their studies of how people learn. From such work came a host of new theories on the subject of intelligence. One prominent concept developed by philosopher Nelson Goodman suggested that the way people 
express themselves and acquire knowledge is through their use of symbols and, while scientists and artists differ in how they use their symbols, neither offer a superior approach to knowledge.

While there is no agreed-upon definition of what critical thinking is or how it can be developed, cognitive researchers and educators struggle to identify what can generally be agreed upon, including "how can critical thinking be fostered or taught?" The concern is that it cannot be taught in isolation, but must be included in content knowledge and opportunities must be provided for students to practice skills so they can become engrained and transferred to other situations (Strauss, 2008). Willingham, a critic of teaching critical thinking, does agree that processes can work with factual knowledge (as cited in Strauss, 2008). More Recent Interest in Cognition in the Arts

Recent findings in cognitive science and neuroscience are now helping to explain arts as a powerful tool to enhance teaching and learning, showing that the brain and body make up a single, fully integrated cognitive system. Researchers have found that most thought occurs on a level well below conscious control and awareness and involves a continual stream of sensory information (Gullatt, 2008). They posit that the very emotional and personal content of the arts are part of what causes the arts to become cognitively powerful (Gullatt, 2008).

The work of Arthur Efland (2002) has become central to understanding the relationship between art and cognition. His work offers a strong argument for the possibility of transfer, providing a research base for seeing works of art as social conventions, in that a person grasps meaning from the art form in various ways, including the social context, often through verbal mediation. It is particularly important, he claims, to direct learning to the understanding that a society is reflected in its art and that the artist plays a central role in representing that society. Efland (2002) also demonstrates imagination as the cognitive process that enables 
individuals to organize or reorganize images, bringing innovation to the creation of meanings that are generally less dependent on conventional ways of thinking. It is necessary, he says, to understand that visual images are embodiments of meanings and, thus, become objects of inquiry. In short, artistry involves cognition. He supports two influential arguments developed by Rudolf Arnheim: sensory perception is already cognitive in that it requires the perceiver to select, generalize, and abstract aspects of the objects received by the mind and representation of objects also requires the ability to think within the means provided by a given medium (Efland). Efland further claims that works of art are also social conventions in that one grasps meaning from the art form in various ways, including social context, often through verbal mediation, i.e., teaching.

Elliot Eisner (2002) examines how the arts contribute to the growth of mind. He unabashedly argues that the ability to create a form of experience that can be regarded as aesthetic requires a "mind that animates our imaginative capacities," be it visual, choreographic, musical, dramatic, literary, or poetic: ergo, the arts require many forms of thinking. Eisner reminds us that we initially learn of our environment through sights and sounds, tastes, and smells which are the first avenues to consciousness and become a means through which we pursue development, reminding us that a major cognitive function the arts perform is to help us notice the world in new ways and to prompt awareness not previously noticed.

Although Eisner insists that the value of the arts does not reside in the linkages with math and language (cited in Brown, 2001), he remains a staunch supporter of the essentialness of learning processes and imaginative thinking in all disciplines (cited in Darby \& Catterall, 1994), and he argues that the arts can serve as models of what educational aspiration and practice can be. His five principles of art education have helped to guide other researchers who agree with 
him that each field of study provides a framework through which children experience, organize, and understand the world by the use of different techniques and materials.

\section{Impact of Cognition Research on Arts Education}

Sousa (2006) speaks to the impact shown by neuroscience research of arts instruction on students' cognitive, social, and emotional development — that certain brain areas respond only to music while others are devoted to initiating and coordinating movement. He also notes that studies consistently show advantages to students in schools where the arts are an integral part of the curriculum. Benefits were reported to include Green's findings on the development of the imagination, Csikszentmihalyi's work on greater motivation to learn, and Catterall and Luftig's studies on increased student creativity, lower dropout rates, and increased social skills (Smithrim \& Upitis, 2005). Various studies and reports indicate that students involved in the arts exhibit higher academic achievement than their peers who are not involved in the arts (cited in Smithrrim \& Upitis, 2005). However, it should be noted that in the midst of the research results current at that time (1995-2002), Winner and Cooper (2000) warned researchers and practitioners not to go beyond the evidence and make causal claims where there was only correlation indicated. As a result, researchers next began to look at science, specifically the breakthrough in cognitive science, as a possible link to the influence of the arts on learning. Among the researchers and practitioners who have been doing research and development in cognition as it applies to education are Geoffrey and Renate Caine (1997), Diamond (1998), Jensen (1998), Kovalik (1999), Silver (1995), Stevens (1999), Sylwester (1995), and Wolfe and Sorgen (1990), to name only a few notables of the late $20^{\text {th }}$ Century.

While not as well known, findings of Hurley and Eisan (1997), measuring affective impacts from integrating the arts, note that there is increasing research which supports the belief 
that the arts can enhance learning in other subjects. Tishman, MacGillivray \& Palmer (1999) found that children who were able to draw inferences about fine art were able to transfer their reasoning to images in science. Lopez, Takiff, Kernan and Stone (2000) found a strong relationship between academic and artistic efficacy; findings suggest that "there is a significant cognitive transfer from arts education to other academic areas" (p.1). Further research on this is the monumental work of Winner and Hetland (2000), particularly their meta-analysis of the arts and academic achievement as a special issue of the Journal of Aesthetic Education.

\section{Key Studies}

The guiding principle of the work of Caine and Caine (1997) is that brain research confirms that multiple complex and concrete experiences are essential for meaningful learning and teaching and that everything being learned links to the learner's current experiences, past knowledge, and future behavior. However, the concern of some researchers and practitioners is that "critical thinking" cannot be taught in isolation, but must be included in content knowledge (Lanzi as cited in Strauss, 2008) and opportunities must be provided for students to practice and experience skills that will become engrained and transferred to other situations.

Robert Sylwester (2000) noted,

From my perspective, thinking is somewhat similar in that how one derives conclusions is far more important than the conclusions drawn, for it is the process which includes/excludes and focuses on different aspects toward combining them in a conclusion of action or thought. ... The problem in evaluating arts is our inability of codifying particulars. Most have looked at the results of skills rather than the thinking processes which underpin them. ... If one only looks at specifics of art that may be transferred, rather than focusing on the process, few skills may be demonstrated or 
applied elsewhere. However, the thinking processes are probably used throughout

(Telephone conversation, Sylwester and Witmer, 2/24/00).

Catterall (2002), whose landmark study on transference in 1999 followed 25,000+ students in American schools for ten years, notes a renewed interest in transference and results that show success with at-risk and failing students who "frequently characterize their success as a result of induced or revived enthusiasm for school attained through the arts" (p. 155). He also calls for further inquiry into the "possibility that sustained and deep learning in the arts may cultivate habits of mind and dispositions impacting future problem-solving behavior" (p. 157).

The seminal work of Winner and Hetland (2000) did not show the results expected by arts educators, but provided encouraging findings, including the relationship of the arts to verbal and mathematics skills. Their meta-analysis notes that the study of transfer effects from the arts is important educationally because any transfer effects that do exist can be put to effective use by teachers and scientifically for what it can tell us about how the mind works and how skills are or are not related in the brain. They recommend (1) more rigorously designed, theory-driven, quasiexperimental research with better-conceived comparison groups to draw firmer conclusions about how and when the arts transfer to other subjects and (2) research to move beyond measuring the effects of the arts in terms of test scores, to assess how the arts affect learning in areas that are more difficult to measure. The authors explain they searched exhaustively for all relevant studies published in English from 1950 to 1998 but could find no experimental studies that provided a test of which causal mechanism might underlie academic improvement as a function of arts study. Thus, the research tells only whether there is a correlation between arts study and academic achievement and whether academic achievement improves when students are exposed to the arts, and not causal effects. 
It should be noted, however, that not all agree with the Winner-Hetland approach and findings. Deasey, 2001) cites other analyses that contradict some of what Winner and Hetland (2000) report and notes that arts education research today is at an early stage of its development that the accumulation of studies over time should refine the understanding of both educators and policymakers. Gullatt (2007) also notes that studies on the relationship between the arts and student achievement within academic disciplines have typically been more theoretical than empirical and Eisner (1999) has always cautioned that the purpose of the arts is not to raise achievement in other disciplines.

\section{Implications for Future Research Studies}

In 2004 the Dana Foundation brought together cognitive neuroscientists from seven U.S. universities to study the question of why arts training is associated with higher academic performance. Findings allow for more understanding of how to define and evaluate the possible causal relationship between arts training and the ability of the brain to learn in other cognitive domains (Gazzaniga, 2008). Conclusions are expected to lead to more definitive results cognition.

Even more recently Stevenson and Deasy (2005) found that, through the arts, students become more engaged in school and learn to make meaning of the world from different perspectives, which then helps them make sense of other kinds of information. They further note that the arts and non-arts content and skills are best taught in tandem, with the content and methods of the disciplines woven together for mutual reinforcement, placing students in active and meaningful roles in the classroom and connecting the schools to the students' own lives and cultures.

Both government (Murfee, 1997) and arts organizations periodically list priorities for arts 
education research and, as expected, their lists are similar. The Arts in Education Partnership (AEP) is perhaps the most respected organization for identifying — and sponsoring — areas of research priorities. Their most recent list proposed studies for specific cognitive characteristics and effects of each of the arts forms, their relationships to other domains of learning, and their roles in the intellectual development of children and adolescents (AEP, 2004).

In recent years, an increasing number of school-based research studies strongly suggest connections between cognition, social, and emotional development and the arts. As seen from the evidence discussed above, it has been demonstrated that students in schools where the arts are an integral part of the curriculum tend to be at an advantage academically over students in schools where such is not the case. The students in these studies appear to be making cognitive connections that their counterparts in less arts-infused schools are not. This research has further indicated that arts educators have themselves rationalized supporting the arts in the school curriculum, often presenting as their case that the arts should be studied because they help students improve in other subject areas as well as in school attendance. Hamblen (1993) examined this in a brief review of learning theory and, while she cautions educators not to exaggerate the academic benefits of an arts curriculum without instrumental claims that are firmly grounded in theory and research, she does find many justifications for art education in the body of works (to the date of her research) on learning theory. One of these holds that arts education gives students access to multiform forms of knowing.

The literature suggests strong correlations between involvement in the arts and student achievement with cognitive factors being the tying link. However, the relationships have not yet been shown to be causal. What is needed is a study that will get us one step closer to examining potential causal connections and, perhaps, opening the door to systemic school change. 
Method

This paper builds upon the work of Kienzl, Boachie-Ansah, Lanahan, and Holt (2006) in their descriptive analysis of the prevalence of arts instruction received by first and third grade public school students in their schools using the Early Childhood Longitudinal Study-K data to determine the students' receipt of arts instruction and the changes in weekly arts instruction between the grades. By extending our research to fifth grade and including both school and home-based characteristics, the purpose of this paper is to explore the relationships among those characteristics as they relate to involvement in the arts and its impact on student learning. Five specific research questions were investigated.

1. Is there a significant difference between students who are involved in the arts out-of school and those who are not involved in the arts out-of-school with respect to teacher ratings of student proficiency regarding reading and math concepts?

2. Is there a significant difference in teacher ratings of student proficiency regarding reading and math concepts by race?

3. Is there a significant difference in teacher ratings of student proficiency regarding reading and math concepts by gender?

4. Is there a significant difference between students who have NO arts instruction in school and those who have arts instruction--less than once per week or more--in school with respect to teacher ratings of student proficiency regarding reading and math concepts?

5. Are there any significant differences in teacher ratings of student proficiency regarding reading and math concepts by type of community (Large and Mid-Size City; Large and Mid-Size Suburb and Large Town; and Small Town and Rural)? 


\section{Data Source}

For this paper, the authors analyzed the fifth grade 2004 secondary data from The Early Childhood Longitudinal Study, Kindergarten Class of 1998-99 (ECLS-K) which includes more than 11,600 children. This dataset provides detailed information on children's health, early care and early school experiences. The database includes student demographic and achievement data in addition to principal, teacher, and parent surveys.

The ECLS-K began in Fall of 1998 with a nationally representative sample of approximately 21,000 kindergartners from about 1,000 kindergarten programs, both public and private. These children were followed longitudinally through the eighth grade, with data collections in the fall and spring of kindergarten (1998-99) and first grade (1999-2000), in the spring of third (2002) and fifth grade (2004), and follow-ups in eighth grade (2007). The children included come from both public and private schools and diverse socioeconomic and racial/ethnic backgrounds. As a follow-up to the IES ECLS-K study using kindergarten and third grade data, this research focused on fifth grade data from children and included only children in the regular classroom $(n=8,048)$.

As can be seen in Table 1, there were 3,915 males (48.6\%) and 4,133 females (51.4\%) in the sample. Table 2 displays the composition of the sample by race indicating that approximately $60 \%$ of the sample was white while $40 \%$ were non-white.

\section{Procedure}

This research examined teacher perceptions of reading and mathematics competencies of the proficiency of fifth grade regular classroom students in reading and mathematics. Teachers were asked to rate the extent to which each student was proficient on each competency using a 5point scale $(1=$ Not Yet, $2=$ Beginning, $3=$ In-Progress, $4=$ Intermediate, and $5=$ Proficient $)$. 
The scale reflects teacher perceptions of the degree to which each child has acquired and demonstrated the skills, knowledge, and behaviors as listed below.

$$
\begin{aligned}
& 1=\text { Not yet } \quad \text { Child has not yet demonstrated skill, knowledge, or behavior. } \\
& 2=\text { Beginning Child is just beginning to demonstrate skill, knowledge, or behavior } \\
& \text { but does so very inconsistently. } \\
& 3=\text { In progress Child demonstrates skill, knowledge, or behavior with some regularity } \\
& \text { but varies in level of competence. } \\
& 4 \text { = Intermediate Child demonstrates skill, knowledge, or behavior with increasing } \\
& \text { regularity and average competence but is not completely proficient. } \\
& 5=\text { Proficient } \quad \text { Child demonstrates skill, knowledge, or behavior competently and } \\
& \text { consistently. }
\end{aligned}
$$

To control for variation in ratings for regular and special needs students, any student with an IEP on file was excluded from the sample. Thus the sample size was reduced to 8,048 children.

T-tests were calculated to determine if there were any significant differences between those students who received some form of arts exposure after school and those who received arts exposure only in school. In addition, t-tests were calculated to determine if there were any significant differences in gender (males $\mathrm{v}$ females) and race (whites $\mathrm{v}$ non-whites). T-tests were also calculated to determine if there were any significant differences between children who had no arts offered as part of the school curriculum and those whose school curriculum included art and/or music. The one-way analysis of variance procedure was used to determine if there were any significant differences among teacher ratings by type of communities (Large and Mid-Size City; Large and Mid-Size Suburb and Large Town; and Small Town and Rural). Finally, teacher ratings were compared by SES group (quintiles) on both reading and mathematics. 


\section{Findings}

The first research question focused on determining if there were any significant differences between students who were involved in the arts out-of-school and those who were not involved in the arts out-of-school with respect to teacher ratings of student proficiency regarding reading and math concepts. Table 3 indicates the results of $\mathrm{t}$-test comparisons between the two groups. As can be seen in the right column of Table 3, all comparisons were significant. For all reading and mathematics competencies, students who took dance, art, or music lessons and/or participated in organized performances outperformed their peers who only had exposure to arts instruction included in the school curriculum.

The second and third research questions examined the extent to which there were significant differences in gender and race with respect to teacher ratings of student proficiency on reading and mathematics competencies. In Table 4, readers can see there are significant differences on all reading competencies. In each case, females scored significantly higher than males in reading. Interestingly, the results for mathematics show that girls are not significantly different than boys in seven of the ten competencies showing that the historical gap between girls and boys is closing. As can be seen in Table 5, whites scored significantly higher than nonwhites in all reading competencies and all but one math competency. There was no significant difference between whites and non-whites in recognizing shape properties in mathematics.

The fourth research question sought to determine if there were any significant differences between teacher ratings of student proficiency on reading and mathematics competencies between students who had no arts instruction in school and those students whose schools included regular arts instruction. Table 6 indicates that students in schools with no arts instruction scored significantly lower in reading than those schools with arts instruction. In 
addition, the same pattern occurred in mathematics for eight of the ten competencies. Only "subtracts number that requires regrouping" and "recognizes shape properties" were not significantly different.

Research question number five examined the teacher ratings of reading and mathematics competencies by type of community (Large \& Mid-Size City, Large \& Mid-Size Suburb \& Large Town, and Small Town \& Rural). Tables 7 and 8 indicate that there are significant differences among the three types of communities on both reading and mathematics competencies. The right-hand column of each table indicates the results of the post hoc tests to determine which group(s) was/were significantly different from each other. In general, Large \& Mid-Size City and Large \& Mid-Size Suburb and Large Town groups were not significantly different from each other but they were different from the Small Town \& Rural group. Only one competency in reading (Reflects on Writing) and two in mathematics (Subtracts number that requires regrouping; Uses measuring tools accurately) had a different result.

Table 9 describes how the frequency of art/music offerings in school differ by type of community. Noted in Table 9, the highest concentration of those never having music in school is in Large \& Mid-Size City and the Small Town \& Rural groups (19.2\% and 18.5\% respectively), typically the less wealthy schools. Further, readers can see that the Large \& Mid-Size Suburb \& Large Town group tends to offer art and music more frequently than the other two groups.

Table 10 indicates the extent to which students have dance, music, and art lessons or participate in organized performances by type of community. Small Town \& Rural schools tend to have fewer opportunities for students to participate in the arts with Large \& Mid-Size Suburb \& Large Town group appearing to have more opportunities. The researchers speculate that the results in Tables 9 and 10 may be highly related to SES and school district wealth. 


\section{Discussion}

This study began with the goal of exploring the relationship of school and home-based characteristics related to involvement in the arts and its impact on student learning. The ECLS-K data at Grade 5 offered rich data to inform this investigation. Also, the IES work done with the Grade 3 ECLS-K afforded additional insight for the following discussion. Our review of the literature exposed the complexity of defining the learning process as well as the work which continues to fall short of proving a causal relationship between the engagement in the arts and enhanced achievement.

Bransford et al. (2000) in their comprehensive work on learning defined this process as dynamic, embedded within a complex ecological context which is inextricably linked to cognitive construction in community. Accepting this definition, our study required a careful look into the school context in which the arts are found as well as the home context. The ECLS-K database supplied us with two key variables that have been noted in the literature to be factors when considering the impact of the engagement of the arts on student learning; school community and family involvement. Two findings emerged which are particularly noteworthy.

First, the location of the public school has long been a focal point of equity of access and distribution in funding and impacting arts opportunities (AEP, 2004) as well as academic success (Kozol, 1992) with a particular focus on the urban schools. Although our study predictably revealed that large and mid-size city (urban) schools have the highest concentration of never having arts/music offerings in school, it is important to note that the rural schools also were found to have a significantly high concentration of never offering art in the schools. It has been postulated through anecdotal evidence that when funding is cut for such components as the arts, schools located in urban areas, which are historically funded at a lower level than those in the 
suburbs, would have less arts involvement. What is noteworthy, however, is that the teacherreported student math and reading competencies were not significantly different between urban and suburban schools but both were different from the rural schools. We suggest this enhances the current arts in schools discourse in two ways.

First, this foregrounds the rural schools in a way that reflects growth in the United States. According to the U.S. census (2000), in 1990s there was a $12 \%$ growth in rural areas and $14 \%$ growth in urban areas nationally. In the Commonwealth of Pennsylvania, according to the U.S. census, the rural areas recorded more growth (4\%) than the urban areas (3\%). Also, if there is little difference between urban schools and suburban schools in most math and reading competencies and yet a significant difference in the amount of opportunities provided for students to engage in the arts in school, these results would suggest that the impact arts engagement has on learning is not necessarily grounded in the number of opportunities a student has within a week, but rather whether or not there is access at all to arts engagement. Researchers have recently begun to address the needs of the arts in rural education settings but more is needed (Duffy \& Friend, 2003). It may prove informative to disaggregate the data on the arts into type of arts engagement such as music, theater, dance, and visual arts to get a richer view of the access and impact of these on students attending schools in one of these types of communities.

Second, it may be suggested that family involvement, as it relates to arts engagement of their children, would significantly impact learning. Identifying the out-of-school arts engagement as one indicator of family involvement, we looked at any difference between those with out-ofschool arts engagement and their achievement in reading and math and those with only in-school arts engagement. Our findings revealed that there were significant differences between these, suggesting the possibility that family involvement in such activities as out-of-school arts does 
introduce a stronger base for math and reading competencies. This exposes the possible need to look at individual student factors and family factors impacting the connection between arts and academic competency. Such factors as dispositions and motivation of the student may be important to explore further to enhance this conversation. Similarly, family factors such as parental involvement, parent education levels, and income may play a role in these differences. This paper's findings indicate a need to further explore the student who engages in arts, thus suggesting a look at such issues as frames of mind (Gardner, 1983) and mindset (Dweck, 2002) to more clearly inform what the data reveal.

The literature on arts education seeks to understand how engagement in the arts affects student's cognition. As noted in the earlier part of this paper, the pursuant discourse on this subject reveals a plethora of definitions of cognition reaping multiple perspectives related to the arts impact on cognition. The majority of the work seeks a causal effect between arts and achievement which, particularly in this present climate of high stakes testing, is presumed to play a powerful role in providing the policy makers and teachers the much needed will and support for retaining arts in school despite budget cuts and the present high stakes testing environment (AEP, 2004). This causal effect, however, remains elusive. The complexity of the learning process continues to stymie this type of study.

In light of this, it is important to note that our analyses make a strong case for further exploring engagement in the arts in school defining cognition as a part of the dynamic whole of the learning process embedded in context (Bransford, et al., 2000). This suggests framing future studies to explore the transformative nature of including the arts in our schools. Even when some form of the arts is only offered less than one time a week, our findings revealed a significant different between what is reported to be the achievement of the fifth grade students who were not 
involved in any out-of-school arts program. This pervasive impact, that appears to be irrespective of race, gender, and type of community in which the school is located, cries for additional exploration.

Therefore, this relationship of the arts to math and reading competencies, as confirmed in this paper, may necessitate a renewed look at Eisner's (2002) contention that the necessary focus for understanding the impact of arts on learning is not academic competencies but the introduction of the "imaginative mind." Bransford et al. (2000) in their comprehensive work on the learning process made it clear that learning is about a dynamic interplay of the developing learner in a complex ecological context. They noted that learning was not about what strategy may cause learners to score better in math or reading but about working with this complex system we call learning in context. The arts, as Eisner contended, and as our findings suggest, may best be considered as key to this transformative thinking about enhancing the learning process in our schools. As noted in the recent joint-venture report of the Arts Education Partnership and The President's Committee on the Arts and the Humanities, the Chicago Arts Partnerships in Education (CAPE) project noted that when arts were introduced into the city schools, the school culture was transformed and conditions for learning improved (Catterall \& Waldorf, n.d.).

When considering such issues as the arts as an agent of school culture transformation, the issues of diversity and culture may be addressed. In the present context movement from a local mentality to a global understanding challenges our schools. Researchers have found that engagement in the arts enhances understanding among diverse groups (Mandall \& Wolf, 2003). The pattern recognition and visualization skills obtained in music engagement are known to be important in developing cross-cultural understanding (Gärdenfors, 2007). The approach of 
exploring arts engagement and learning as defined in context or socioculturally (Vygotsky, 1978) may be the necessary focus to move the arts in schools out of the ordinary funding discourse and into the transformative education discourse ( Hick, Berger \& Generett, 2005).

\section{Limitations and Future Research}

Although this discussion exposes a broad understanding of the relationship between arts in schools and community and home-based factors, we recognize there are clearly limitations in our work to this point. First, defining reading and math competencies by teacher reports has its limitations. This process does not take into account the possibility of teacher biases which may be present within this reporting process but it also does not provide for a broader understanding of the learning process found to be more efficacious in studies focusing on arts in school (Eisner, 2002; Fiske, n.d.). Second, the aggregating of arts as one entity is limiting. To enrich this study, disaggregating the data defined by music, drama, theater, and visual arts may prove more helpful for discerning the primary sources of impact, particularly for those math and reading competencies which appeared significantly different with arts engagement than without.

On the other hand, our findings reflect a key issue with rural schools and the impact of even a few arts opportunities in schools provide a framework for exploring arts engagement and the learning process as an embedded dynamic whole. It is anticipated that this exploration has the potential of adding to the discourse relating the complexities of student learning within a dynamic context and ever-changing family constellations.

\section{Conclusion}

As we consider engagement in the arts and home-based as well as community-based factors we find the work has just begun. As we anticipate the dynamic school context which is embedded within a globalized society, the exploration of the relationship of the arts in schools 
and student learning may not be fully understood without a comprehensive dynamic understanding of learning which unleashes "imaginative thought" (Eisner, 2002). It is with this frame of mind concerning the arts in school that we look toward informing the discourse at a broader and deeper level as research moves forward into a transformative understanding. 
Table 1: Counts and Percents by Gender $(n=8,048)$

\begin{tabular}{|c|c|c|}
\hline Gender & Count & Percent \\
\hline Male & 3915 & 48.6 \\
\hline Female & 4133 & 51.4 \\
\hline
\end{tabular}

Table 2: Counts and Percent by Race $(n=8,048)$

\begin{tabular}{|l|c|c|}
\hline \multicolumn{1}{|c|}{ Race } & Count & Percent \\
\hline White, Non-Hispanic & 4833 & 60.1 \\
\hline $\begin{array}{l}\text { Black Or African American, } \\
\text { Non-Hispanic }\end{array}$ & 858 & 10.7 \\
\hline Hispanic, Race Specified & 671 & 8.3 \\
\hline Hispanic, Race Not Specified & 647 & 8.0 \\
\hline Asian & 601 & 7.5 \\
\hline $\begin{array}{l}\text { Native Hawaiian, Other } \\
\text { Pacific Islander }\end{array}$ & 103 & 1.3 \\
\hline $\begin{array}{l}\text { American Indian Or Alaska } \\
\text { Native }\end{array}$ & 133 & 2.7 \\
\hline $\begin{array}{l}\text { More Than One Race, Non } \\
\text { Hispanic }\end{array}$ & 196 & 2.4 \\
\hline
\end{tabular}


Table 3: Comparison of students who only have arts in-school and those who also have out-ofschool arts: Reading and Mathematics Competencies

\begin{tabular}{|c|c|c|c|c|c|}
\hline \multirow[t]{2}{*}{$\begin{array}{c}\text { Reading } \\
\text { Competencies }\end{array}$} & \multicolumn{2}{|c|}{$\begin{array}{l}\text { Arts In-School Only } \\
\quad(n=3,357)\end{array}$} & \multicolumn{2}{|c|}{$\begin{array}{l}\text { Arts In-School } \\
\text { and Out-of School } \\
\quad(\mathrm{n}=4,518)\end{array}$} & \multirow[b]{2}{*}{ t-value } \\
\hline & Mean & SD & Mean & S.D. & \\
\hline $\begin{array}{l}\text { 1. Conveys ideas clearly when } \\
\text { speaks }\end{array}$ & 3.61 & 1.02 & 3.91 & .94 & $-13.17 * * *$ \\
\hline $\begin{array}{l}\text { 2. Understands and interprets } \\
\text { text read aloud }\end{array}$ & 3.70 & .97 & 3.99 & .90 & $-13.46 * * *$ \\
\hline $\begin{array}{l}\text { 3. Uses strategies to gain } \\
\text { information }\end{array}$ & 3.42 & 1.01 & 3.71 & .95 & $-12.49 * * *$ \\
\hline 4. Reads books fluently & 3.72 & 1.00 & 4.00 & .94 & $-12.76 * * *$ \\
\hline $\begin{array}{l}\text { 5. Reads and comprehends } \\
\text { expository text }\end{array}$ & 3.53 & 1.00 & 3.80 & .95 & $-11.92 * * *$ \\
\hline $\begin{array}{l}\text { 6. Composes multi-paragraph } \\
\text { story }\end{array}$ & 3.42 & 1.00 & 3.74 & .98 & $-13.84 * * *$ \\
\hline 7. Reflects on writing & 3.23 & .99 & 3.54 & .98 & $-13.55 * * *$ \\
\hline $\begin{array}{l}\text { 8. Makes mechanical } \\
\text { corrections }\end{array}$ & 3.40 & .98 & 3.68 & .95 & $-12.60 * * *$ \\
\hline $\begin{array}{c}\text { Mathematics } \\
\text { Competencies }\end{array}$ & \multicolumn{2}{|c|}{$\mathrm{n}=1,640$} & \multicolumn{2}{|c|}{$\mathrm{n}=2,266$} & \\
\hline $\begin{array}{l}\text { 1. Subtracts number that } \\
\text { requires regrouping }\end{array}$ & 4.43 & .76 & 4.56 & .67 & $-5.58 * * *$ \\
\hline $\begin{array}{l}\text { 2. Reduces fractions to lowest } \\
\text { denominator }\end{array}$ & 3.38 & 1.14 & 3.65 & 1.12 & $-6.97 * * *$ \\
\hline 3. Money management skills & 3.18 & 1.11 & 3.41 & 1.09 & $-6.09 * * *$ \\
\hline $\begin{array}{l}\text { 4. Recognizes shape } \\
\text { properties }\end{array}$ & 3.41 & 1.04 & 3.58 & 1.05 & $-4.70 * * *$ \\
\hline $\begin{array}{l}\text { 5. Uses measuring tools } \\
\text { accurately }\end{array}$ & 3.51 & .99 & 3.74 & .95 & $-7.17 * * *$ \\
\hline 6. Understands place value & 4.00 & .97 & 4.20 & .90 & $-6.66 * * *$ \\
\hline $\begin{array}{l}\text { 7. Estimates quantities and } \\
\text { checks answers }\end{array}$ & 3.63 & 1.02 & 3.85 & .98 & $6.72 * * *$ \\
\hline $\begin{array}{l}\text { 8. Uses strategies for math } \\
\text { problems }\end{array}$ & 3.54 & 1.08 & 3.79 & 1.03 & $-7.16 * * *$ \\
\hline $\begin{array}{l}\text { 9. Divides multi-digit } \\
\text { problems }\end{array}$ & 3.85 & 1.06 & 4.10 & .97 & $-7.36 * * *$ \\
\hline $\begin{array}{l}10 . \text { Demonstrate algebraic } \\
\text { thinking }\end{array}$ & 3.33 & 1.10 & 3.58 & 1.10 & $-6.78 * * *$ \\
\hline
\end{tabular}

Arts In-School and Out-of-school includes students who receive arts instruction during the school day in addition to one or more of the following outside of school: art lessons, music lessons, dance lessons, performances. Arts In-School Only includes students who receive only what is offered during the school day with no out-of-school arts classes.

$* * * \mathrm{p} \leq .001$ 
Table 4: Comparison of Reading Competencies by Gender

\begin{tabular}{|c|c|c|c|c|c|}
\hline \multirow{2}{*}{$\begin{array}{c}\text { Reading } \\
\text { Competencies }\end{array}$} & \multicolumn{2}{|c|}{$\begin{array}{c}\text { Male } \\
(\mathrm{n}=3,827)\end{array}$} & \multicolumn{2}{|c|}{$\begin{array}{c}\text { Female } \\
(\mathrm{n}=4,048)\end{array}$} & \multirow[b]{2}{*}{$\mathrm{t}$-value } \\
\hline & Mean & SD & Mean & S.D. & \\
\hline $\begin{array}{l}\text { 1. Conveys ideas clearly when } \\
\text { speaks }\end{array}$ & 3.68 & 1.01 & 3.89 & .96 & $9.49 * * *$ \\
\hline $\begin{array}{l}\text { 2. Understands and interprets } \\
\text { text read aloud }\end{array}$ & 3.80 & .97 & 3.93 & .92 & $5.88 * * *$ \\
\hline $\begin{array}{l}\text { 3. Uses strategies to gain } \\
\text { information }\end{array}$ & 3.50 & 1.02 & 3.67 & .95 & $7.48 * * *$ \\
\hline 4. Reads books fluently & 3.76 & 1.00 & 3.99 & .94 & $10.31 * * *$ \\
\hline $\begin{array}{l}\text { 5. Reads and comprehends } \\
\text { expository text }\end{array}$ & 3.62 & 1.01 & 3.75 & .95 & $5.93 * * *$ \\
\hline $\begin{array}{l}\text { 6. Composes multi-paragraph } \\
\text { story }\end{array}$ & 3.45 & 1.01 & 3.75 & .97 & $13.64 * * *$ \\
\hline 7. Reflects on writing & 3.23 & 1.00 & 3.57 & .97 & $15.15 * * *$ \\
\hline $\begin{array}{l}\text { 8. Makes mechanical } \\
\text { corrections }\end{array}$ & 3.39 & .99 & 3.73 & .93 & $15.51 * * *$ \\
\hline $\begin{array}{l}\text { Mathematics } \\
\text { Competencies }\end{array}$ & \multicolumn{2}{|c|}{$(\mathrm{n}=1,877)$} & \multicolumn{2}{|c|}{$(\mathrm{n}=2,029)$} & \\
\hline $\begin{array}{l}\text { 1. Subtracts number that } \\
\text { requires regrouping }\end{array}$ & 4.52 & .71 & 4.49 & .73 & 1.43 \\
\hline $\begin{array}{l}\text { 2. Reduces fractions to lowest } \\
\text { denominator }\end{array}$ & 3.53 & 1.16 & 3.54 & 2.22 & .35 \\
\hline 3. Money management skills & 3.35 & 1.14 & 3.28 & 2.22 & 1.78 \\
\hline $\begin{array}{l}\text { 4. Recognizes shape } \\
\text { properties }\end{array}$ & 3.52 & 1.05 & 3.49 & 2.05 & .85 \\
\hline $\begin{array}{l}\text { 5. Uses measuring tools } \\
\text { accurately }\end{array}$ & 3.69 & .99 & 3.60 & .96 & $2.64 * *$ \\
\hline 6. Understands place value & 4.16 & .92 & 4.09 & .94 & $2.27 *$ \\
\hline $\begin{array}{l}\text { 7. Estimates quantities and } \\
\text { checks answers }\end{array}$ & 3.81 & 1.00 & 3.72 & 1.01 & $2.67 * *$ \\
\hline $\begin{array}{l}\text { 8. Uses strategies for math } \\
\text { problems }\end{array}$ & 3.70 & 1.07 & 3.67 & 1.05 & 1.04 \\
\hline $\begin{array}{l}\text { 9. Divides multi-digit } \\
\text { problems }\end{array}$ & 4.03 & 1.02 & 3.96 & 1.01 & $2.31 *$ \\
\hline $\begin{array}{l}\text { 10. Demonstrate algebraic } \\
\text { thinking }\end{array}$ & 3.51 & 1.12 & 3.45 & 1.09 & 1.57 \\
\hline $\mathrm{p} \leq .05$ & & & & & \\
\hline $\begin{array}{ll}* * & \mathrm{p} \leq .01 \\
* * * & \mathrm{p}<.001\end{array}$ & & & & & \\
\hline
\end{tabular}


Table 5: Comparison of Reading Competencies by Race

\begin{tabular}{|c|c|c|c|c|c|}
\hline \multirow{2}{*}{$\begin{array}{c}\text { Reading } \\
\text { Competencies }\end{array}$} & \multicolumn{2}{|c|}{$\begin{array}{c}\text { White } \\
(\mathrm{n}=4,767)\end{array}$} & \multicolumn{2}{|c|}{$\begin{array}{l}\text { Non-White } \\
(\mathrm{n}=3,102)\end{array}$} & \multirow[b]{2}{*}{ t-value } \\
\hline & Mean & SD & Mean & S.D. & \\
\hline $\begin{array}{l}\text { 1. Conveys ideas clearly when } \\
\text { speaks }\end{array}$ & 3.86 & .96 & 3.67 & 1.02 & $8.28 * * *$ \\
\hline $\begin{array}{l}\text { 2. Understands and interprets } \\
\text { text read aloud }\end{array}$ & 3.95 & .92 & 3.75 & .97 & $8.97 * * *$ \\
\hline $\begin{array}{l}\text { 3. Uses strategies to gain } \\
\text { information }\end{array}$ & 3.65 & .96 & 3.48 & 1.03 & $7.33 * * *$ \\
\hline 4. Reads books fluently & 3.95 & .95 & 3.76 & 1.00 & $8.29 * * *$ \\
\hline $\begin{array}{l}\text { 5. Reads and comprehends } \\
\text { expository text }\end{array}$ & 3.77 & .96 & 3.56 & 1.00 & $9.23 * * *$ \\
\hline $\begin{array}{l}\text { 6. Composes multi-paragraph } \\
\text { story }\end{array}$ & 3.68 & .98 & 3.49 & 1.03 & $7.78 * * *$ \\
\hline 7. Reflects on writing & 3.48 & .98 & 3.30 & 1.02 & $7.92 * * *$ \\
\hline $\begin{array}{l}\text { 8. Makes mechanical } \\
\text { corrections }\end{array}$ & 3.63 & .96 & 3.46 & .99 & $7.56 * * *$ \\
\hline $\begin{array}{l}\text { Mathematics } \\
\text { Competencies }\end{array}$ & \multicolumn{2}{|c|}{$(\mathrm{n}=2,376)$} & \multicolumn{2}{|c|}{$(\mathrm{n}=2,527)$} & \\
\hline $\begin{array}{l}\text { 1. Subtracts number that } \\
\text { requires regrouping }\end{array}$ & 4.56 & .66 & 4.43 & .78 & $5.26 * * *$ \\
\hline $\begin{array}{l}\text { 2. Reduces fractions to lowest } \\
\text { denominator }\end{array}$ & 3.58 & 1.14 & 3.47 & 1.12 & $2.83 * *$ \\
\hline 3. Money management skills & 3.36 & 1.08 & 3.24 & 1.14 & $3.00 * *$ \\
\hline $\begin{array}{l}\text { 4. Recognizes shape } \\
\text { properties }\end{array}$ & 3.53 & 1.03 & 3.47 & 1.07 & 1.75 \\
\hline $\begin{array}{l}\text { 5. Uses measuring tools } \\
\text { accurately }\end{array}$ & 3.73 & .95 & 3.51 & 1.00 & $6.55 * * *$ \\
\hline 6. Understands place value & 4.18 & .90 & 4.03 & .98 & $4.76 * * *$ \\
\hline $\begin{array}{l}\text { 7. Estimates quantities and } \\
\text { checks answers }\end{array}$ & 3.83 & .97 & 3.66 & 1.05 & $5.01 * * *$ \\
\hline $\begin{array}{l}\text { 8. Uses strategies for math } \\
\text { problems }\end{array}$ & 3.76 & 1.03 & 3.57 & 1.09 & $5.38 * * *$ \\
\hline $\begin{array}{l}\text { 9. Divides multi-digit } \\
\text { problems }\end{array}$ & 4.07 & .96 & 3.87 & 1.09 & $5.66 * * *$ \\
\hline $\begin{array}{l}\text { 10. Demonstrate algebraic } \\
\text { thinking }\end{array}$ & 3.52 & 1.09 & 3.41 & 1.12 & $2.87 * *$ \\
\hline
\end{tabular}


Table 6: Comparison of Reading and Mathematics Competencies by Students who No Art or Music Instruction In-School with Students Who Do

\begin{tabular}{|c|c|c|c|c|c|}
\hline \multirow[t]{2}{*}{$\begin{array}{c}\text { Reading } \\
\text { Competencies }\end{array}$} & \multicolumn{2}{|c|}{$\begin{array}{c}\text { No Arts Instruction In- } \\
\text { School } \\
(\mathrm{n}=827)\end{array}$} & \multicolumn{2}{|c|}{$\begin{array}{l}\text { Arts Instruction } \\
\text { In-School } \\
(\mathrm{n}=6,598)\end{array}$} & \multirow[b]{2}{*}{ t-value } \\
\hline & Mean & SD & Mean & S.D. & \\
\hline $\begin{array}{l}\text { 1. Conveys ideas clearly when } \\
\text { speaks }\end{array}$ & 3.69 & 1.07 & 3.80 & .98 & $2.68 * * *$ \\
\hline $\begin{array}{l}\text { 2. Understands and interprets } \\
\text { text read aloud }\end{array}$ & 3.76 & 1.00 & 3.88 & .94 & $3.36 * *$ \\
\hline $\begin{array}{l}\text { 3. Uses strategies to gain } \\
\text { information }\end{array}$ & 3.39 & 1.10 & 3.61 & .97 & $5.22 * * *$ \\
\hline 4. Reads books fluently & 3.71 & 1.07 & 3.90 & .96 & $4.88 * * *$ \\
\hline $\begin{array}{l}\text { 5. Reads and comprehends } \\
\text { expository text }\end{array}$ & 3.52 & 1.08 & 3.71 & .97 & $4.72 * * *$ \\
\hline $\begin{array}{l}\text { 6. Composes multi-paragraph } \\
\text { story }\end{array}$ & 3.40 & 1.11 & 3.64 & .98 & $5.81 * * *$ \\
\hline 7. Reflects on writing & 3.22 & 1.08 & 3.44 & .98 & $5.44 * * *$ \\
\hline $\begin{array}{l}\text { 8. Makes mechanical } \\
\text { corrections }\end{array}$ & 3.34 & 1.04 & 3.60 & .96 & $6.77 * * *$ \\
\hline $\begin{array}{l}\text { Mathematics } \\
\text { Competencies }\end{array}$ & \multicolumn{2}{|c|}{$(n=404)$} & \multicolumn{2}{|c|}{$(\mathrm{n}=3,287)$} & \\
\hline $\begin{array}{l}\text { 1. Subtracts number that } \\
\text { requires regrouping }\end{array}$ & 4.46 & .79 & 4.51 & .71 & 1.24 \\
\hline $\begin{array}{l}\text { 2. Reduces fractions to lowest } \\
\text { denominator }\end{array}$ & 3.38 & 1.27 & 3.54 & 1.12 & $2.45 *$ \\
\hline 3. Money management skills & 3.10 & 1.25 & 3.35 & 1.08 & $3.39 * * *$ \\
\hline $\begin{array}{l}\text { 4. Recognizes shape } \\
\text { properties }\end{array}$ & 3.40 & 1.24 & 3.51 & 1.02 & 1.57 \\
\hline $\begin{array}{l}\text { 5. Uses measuring tools } \\
\text { accurately }\end{array}$ & 3.43 & 1.11 & 3.66 & .95 & $3.79 * * *$ \\
\hline 6. Understands place value & 3.98 & 1.07 & 4.13 & .92 & $2.58 * *$ \\
\hline $\begin{array}{l}\text { 7. Estimates quantities and } \\
\text { checks answers }\end{array}$ & 3.62 & 1.08 & 3.77 & 1.00 & $2.69 * *$ \\
\hline $\begin{array}{l}\text { 8. Uses strategies for math } \\
\text { problems }\end{array}$ & 3.53 & 1.16 & 3.70 & 1.04 & $2.69 * *$ \\
\hline $\begin{array}{l}\text { 9. Divides multi-digit } \\
\text { problems }\end{array}$ & 3.77 & 1.18 & 4.00 & 1.00 & $3.66 * * *$ \\
\hline $\begin{array}{l}10 . \text { Demonstrate algebraic } \\
\text { thinking }\end{array}$ & 3.26 & 1.16 & 3.49 & 1.10 & $3.77 * * *$ \\
\hline
\end{tabular}

No Arts Instruction=No music or art classes are offered as part of the in-school curriculum. In-School Arts Instruction=Art and/or Music classes held in-school ranging in frequency from less than once per week to five times per week. * $\mathrm{p} \leq .05, * * \mathrm{p} \leq .01$, $* * * \mathrm{p} \leq .001$ 
Table 7: Comparison of Reading Competencies by Type of Community

\begin{tabular}{|c|c|c|c|c|c|c|c|c|}
\hline \multirow[t]{2}{*}{$\begin{array}{c}\text { Reading } \\
\text { Competencies }\end{array}$} & \multicolumn{2}{|c|}{$\begin{array}{l}\text { Large \& Mid-Size } \\
\text { City } \\
\quad(n=2,783)\end{array}$} & \multicolumn{2}{|c|}{$\begin{array}{c}\text { Large \& Mid-Size } \\
\text { Suburb \& Large Town } \\
\quad(\mathrm{n}=3,000)\end{array}$} & \multicolumn{2}{|c|}{$\begin{array}{l}\text { Small Town \& Rural } \\
\qquad(\mathrm{n}=1,946)\end{array}$} & & \multirow[t]{2}{*}{$\begin{array}{c}\text { Group } \\
\text { Comparisons }\end{array}$} \\
\hline & Mean & $\mathrm{SD}$ & Mean & SD & Mean & $\mathrm{SD}$ & F-ratio & \\
\hline $\begin{array}{l}\text { 1. Conveys ideas clearly } \\
\text { when speaks }\end{array}$ & 3.80 & 1.00 & 3.84 & 1.00 & 3.68 & .97 & $15.28 * * *$ & $(1=2) \neq 3$ \\
\hline $\begin{array}{l}\text { 2. Understands and } \\
\text { interprets text read aloud }\end{array}$ & 3.88 & .96 & 3.89 & .95 & 3.80 & .93 & $6.02 * * *$ & $(1=2) \neq 3$ \\
\hline $\begin{array}{l}\text { 3. Uses strategies to gain } \\
\text { information }\end{array}$ & 3.60 & .99 & 3.62 & .98 & 3.48 & 1.00 & $12.20 * * *$ & $(1=2) \neq 3$ \\
\hline 4. Reads books fluently & 3.88 & 1.00 & 3.93 & .96 & 3.77 & .98 & $15.00 * * *$ & $(1=2) \neq 3$ \\
\hline $\begin{array}{l}\text { 5. Reads and comprehends } \\
\text { expository text }\end{array}$ & 3.68 & .98 & 3.75 & .98 & 3.58 & 1.00 & $17.05 * * *$ & $(1=2) \neq 3$ \\
\hline $\begin{array}{l}\text { 6. Composes multi- } \\
\text { paragraph story }\end{array}$ & 3.60 & .99 & 3.66 & .99 & 3.51 & 1.04 & $13.14 * * *$ & $(1=2) \neq 3$ \\
\hline 7. Reflects on writing & 3.40 & .99 & 3.46 & 1.00 & 3.33 & 1.03 & $10.61 * * *$ & $(1=3)(2=3)(2 \neq 3)$ \\
\hline $\begin{array}{l}\text { 8. Makes mechanical } \\
\text { corrections }\end{array}$ & 3.53 & .97 & 3.63 & .97 & 3.50 & .99 & $10.97 * * *$ & $(1=2) \neq 3$ \\
\hline
\end{tabular}

${ }^{1}$ Large \& Mid-Size City = 1; Large \& Mid-Size Suburb \& Large Town=2; Small Town \& Rural=3

$\begin{array}{ll}* & \mathrm{p} \leq .05 \\ * * & \mathrm{p} \leq .01 \\ * * * & \mathrm{p} \leq .001\end{array}$ 
Table 8: Comparison of Mathematics Competencies by Type of Community

\begin{tabular}{|c|c|c|c|c|c|c|c|c|}
\hline \multirow[t]{2}{*}{$\begin{array}{l}\text { Mathematics } \\
\text { Competencies }\end{array}$} & \multicolumn{2}{|c|}{$\begin{array}{l}\text { Large \& Mid-Size } \\
\text { City } \\
(\mathrm{n}=1,330)\end{array}$} & \multicolumn{2}{|c|}{$\begin{array}{c}\text { Large \& Mid-Size } \\
\text { Suburb \& Large Town } \\
(\mathrm{n}=1,473)\end{array}$} & \multicolumn{2}{|c|}{$\begin{array}{l}\text { Small Town \& Rural } \\
\qquad(\mathrm{n}=949)\end{array}$} & \multirow[b]{2}{*}{ F-ratio } & \multirow[t]{2}{*}{$\begin{array}{c}\text { Group } \\
\text { Comparisons }\end{array}$} \\
\hline & Mean & SD & Mean & SD & Mean & SD & & \\
\hline $\begin{array}{l}\text { 1. Subtracts number that } \\
\text { requires regrouping }\end{array}$ & 4.49 & .74 & 4.56 & .66 & 4.43 & .75 & $10.40 * * *$ & $\begin{array}{c}1=3,2=3, \\
1 \neq 2\end{array}$ \\
\hline $\begin{array}{l}\text { 2. Reduces fractions to } \\
\text { lowest denominator }\end{array}$ & 3.57 & 1.14 & 3.61 & 1.10 & 3.32 & 1.17 & $18.94 * * *$ & $1,2 \neq 3$ \\
\hline $\begin{array}{l}\text { 3. Money management } \\
\text { skills }\end{array}$ & 3.28 & 1.15 & 3.43 & 1.08 & 3.17 & 1.08 & $14.02 * * *$ & $1,2 \neq 3$ \\
\hline $\begin{array}{l}\text { 4. Recognizes shape } \\
\text { properties }\end{array}$ & 3.51 & 1.05 & 3.56 & 1.07 & 3.37 & 1.02 & $9.28 * * *$ & $1,2 \neq 3$ \\
\hline $\begin{array}{l}\text { 5. Uses measuring tools } \\
\text { accurately }\end{array}$ & 3.63 & .98 & 3.71 & .98 & 3.54 & .97 & $8.23 * * *$ & $\begin{array}{c}1=2,1=3, \\
2 \neq 3\end{array}$ \\
\hline 6. Understands place value & 4.12 & .95 & 4.22 & .86 & 3.97 & .98 & $21.97 * * *$ & $1 \neq 2 \neq 3$ \\
\hline $\begin{array}{l}\text { 7. Estimates quantities and } \\
\text { checks answers }\end{array}$ & 3.76 & 1.02 & 3.85 & .98 & 3.62 & 1.02 & $15.05 * * *$ & $1,2 \neq 3$ \\
\hline $\begin{array}{l}\text { 8. Uses strategies for math } \\
\text { problems }\end{array}$ & 3.69 & 1.07 & 3.78 & 1.00 & 3.51 & 1.09 & $18.70 * * *$ & $1,2 \neq 3$ \\
\hline $\begin{array}{l}\text { 9. Divides multi-digit } \\
\text { problems }\end{array}$ & 4.02 & 1.00 & 4.07 & .96 & 3.82 & 1.10 & $17.54 * * *$ & $1,2 \neq 3$ \\
\hline $\begin{array}{l}\text { 10. Demonstrate algebraic } \\
\text { thinking }\end{array}$ & 3.52 & 1.10 & 3.55 & 1.07 & 3.29 & 1.14 & $17.19 * * *$ & $1,2 \neq 3$ \\
\hline
\end{tabular}

${ }^{1}$ Large \& Mid-Size City = 1; Large \& Mid-Size Suburb \& Large Town=2; Small Town \& Rural=3

$$
\begin{array}{ll}
* & \mathrm{p} \leq .05 \\
* * & \mathrm{p} \leq .01 \\
* * * & \mathrm{p} \leq .001
\end{array}
$$


Table 9: Counts and Percents of Music and Art Classes in the School Curriculum by Type of Community

\begin{tabular}{|c|c|c|c|}
\hline $\begin{array}{l}\text { Frequency of Music } \\
\text { in School Curriculum }\end{array}$ & $\begin{array}{c}\text { Large \& Mid-Size } \\
\text { City }\end{array}$ & $\begin{array}{c}\text { Large \& Mid-Size } \\
\text { Suburb \& Large } \\
\text { Town }\end{array}$ & Small Town \& Rural \\
\hline Never & $490(19.2 \%)$ & $353(12.6 \%)$ & $336(18.5 \%)$ \\
\hline $\begin{array}{c}\text { Less Than Once A } \\
\text { Week }\end{array}$ & $280(11.0 \%)$ & $392(14.0 \%)$ & $200(11.0 \%)$ \\
\hline $\begin{array}{c}\text { Once or Twice a } \\
\text { Week }\end{array}$ & $1647(64.4 \%)$ & $1915(68.2 \%)$ & $1101(60.7 \%)$ \\
\hline $\begin{array}{c}\text { Three or Four Times } \\
\text { a Week }\end{array}$ & $85(3.3 \%)$ & $117(4.2 \%)$ & $128(7.1 \%)$ \\
\hline Daily & $54(2.1 \%)$ & $29(1.0 \%)$ & $49(2.7 \%)$ \\
\hline $\begin{array}{l}\text { Frequency of Art in } \\
\text { School Curriculum }\end{array}$ & -- & -- & -- \\
\hline Never & $490(19.2 \%)$ & $353(12.6 \%)$ & $336(18.5 \%)$ \\
\hline $\begin{array}{c}\text { Less Than Once A } \\
\text { Week }\end{array}$ & $280(11.0 \%)$ & $392(14.0 \%)$ & $200(11.0 \%)$ \\
\hline $\begin{array}{c}\text { Once or Twice a } \\
\text { Week }\end{array}$ & $1647(64.4 \%)$ & $1915(68.2 \%)$ & $1101(60.7 \%)$ \\
\hline $\begin{array}{c}\text { Three or Four Times } \\
\text { a Week }\end{array}$ & $85(3.3 \%)$ & $117(4.2 \%)$ & $128(7.1 \%)$ \\
\hline Daily & $54(2.1 \%)$ & $29(1.0 \%)$ & $49(2.7 \%)$ \\
\hline
\end{tabular}


Table 10: Counts and Percents of Participation in Dance, Music, Arts, and Organized Performances by Type of Community $(n=7,202)$

\begin{tabular}{|c|c|c|c|}
\hline Arts Participation & $\begin{array}{c}\text { Large \& Mid-Size } \\
\text { City }\end{array}$ & $\begin{array}{c}\text { Large \& Mid-Size } \\
\text { Suburb \& Large } \\
\text { Town }\end{array}$ & Small Town \& Rural \\
\hline Takes Dance Lessons & $394(15.4 \%)$ & $428(15.2 \%)$ & $180(9.8 \%)$ \\
\hline Yes & $2169(84.6 \%)$ & $2379(84.8 \%)$ & $1652(90.2 \%)$ \\
\hline No & $834(32.5 \%)$ & $991(35.3 \%)$ & $463(25.3 \%)$ \\
\hline Takes Music Lessons & $1730(67.5 \%)$ & $1816(64.7 \%)$ & $1369(74.7 \%)$ \\
\hline Yes & $289(11.3 \%)$ & $324(11.5 \%)$ & $184(10.0 \%)$ \\
\hline No & $2275(88.7 \%)$ & $2483(88.5 \%)$ & $1648(90.0 \%)$ \\
\hline Takes Art Lessons & & & $1414(77.2 \%)$ \\
\hline Yes & $1923(75.0 \%)$ & $2055(73.2 \%)$ & $418(22.8 \%)$ \\
\hline No & & & \\
\hline $\begin{array}{c}\text { Organized } \\
\text { Performances }\end{array}$ & & & \\
\hline Yes & & & \\
\hline No & & & \\
\hline
\end{tabular}




\section{References}

Arts Education Partnership (AEP). (2004). The arts and education: New opportunities for research. Retrieved October 4, 2008 from http://www.aep-arts.org

Bransford, J. D, Brown, A. S., \& Cocking, R. R. (Eds.). (2000).How people learn: Brain, mind, experience, and school. Washington DC: National Academy Press.

Brown, N.C. (2001). The meaning of transfer in the practices of arts education. Studies in Arts Education, 43(1), 83-102.

Caine, R.N., \& Caine, G. (1997). Education on the Edge of Possibility. Alexandria, VA: Association of Supervision and Curriculum Development.

Caine, R.N., \& Caine, G. (1991). Making Connections. Alexandria, VA: Association of Supervision and Curriculum Development.

Catterall, J. (2002) “The Arts and the Transfer of Learning," Critical Links: Learning in the Arts and Student Academic and Social Development. Washington, DC: Arts Education Partnership.

Catterall, J. \& Waldorf, L. (2000). Chicago arts partnerships in education: Summary evaluation. In E. Fiske (Ed.), Champions of change: The impact of arts on learning. Washington, DC: Arts Education Partnership and the Presidents' Committee on the Arts and Humanities.

Darby, J., \& Catterall, J. (1994). The fourth R: The arts and learning. Teachers College Record, 96(2), 299-328.

D'Arcangelo, M. (1998). The brains behind the brain. Educational Leadership, 56(3), 20-25.

Deasy, R. (Ed.). (2002) Critical Links: Learning in the arts and student academic and social development. Washington, DC: Arts Education Partnership. 
Diamond, M., \& Hopson, J. (1998). Magic trees of the mind. NY: Penguin Putnam.

Duffy, S., \& Friend, K. (2003). Cal Poly Arts in Education Projects: Changing pedagogy and cultivating the arts in rural school districts. Arts Education Policy Review, 105(2), 3-9.

Efland, A. (2002). Art and cognition: Integrating the visual arts in the curriculum, Teachers College Press, NY: Columbia University.

Eisner, E.(2002). The arts and the creation of mind. New Haven, CT: Yale University Press.

Eisner, E. (November 5, 1999). Conversation with Judith Witmer, The Bellwether Consortium, Milton Hershey School, Reception in The Hotel Hershey, Hershey, PA.

Eisner, E. (1974). Is the artists-in-the-schools program effective? Arts Education 27(2), 19-23.

Fischer, K. \& Rose, S. (1998). How children learn: What cognitive research tells us about effective instruction. Educational Research Service, 1-8.

Fiske, E. B. (Ed.). (n.d.). Champions of change: The impact of the arts on learning. Washington, DC: The Arts Education Partnership.

Gärdenfors, P. (2007). Understanding cultural patterns. In M. Suárez-Orozco (Ed.). Learning in the Global Era: International perspective on globalization and education (pp. 67-84). Los Angeles: University of California Press.

Gazzaniga, M. (2008). Arts and cognition: Findings hint at relationships. The 2008 progress report on brain research. Retrieved September 2008, from http://www.dana.org Gullatt, D. (2008, Spring). Enhancing student learning through arts integration: Implications for the profession. [Electronic version].The High School Journal. 91(4), 12-25.

Gullatt, D. (2007). Research links the arts with student academic gains. The Educational Forum, 7(3), 211-221. 
Hamlen, K.(1993). Theories and research that support art instruction for instrumental outcomes. Theory into Practice. 32(4), 191-198.

Hicks, M. A., Berger, J. G., \& Gernerett, G. (2005). From hope to action: Creating spaces to sustain transformative habits of mind and heart. [Electronic version]. Journal of Transformative Education, 3, 57-75.

Hurley, M. \& Eisan, W. (1996, November). Methods of measuring affective impacts from integrating the arts into core curriculum. Paper presented at the annual conference of the American Evaluation Association, Atlanta, GA.

Jarrett, J. (1993, November/December). The place of art in the education of feeling. Arts Education Policy Review, 95(2), 20.

Jensen, E.(1998). Teaching with the brain in mind. Alexandria, VA: Association of Supervision and Curriculum Development.

Kienzl, G., Boachie-Ansah, G., Lanahan, L., \& Holt, E. W. (2006). Arts instruction of public school students in the first and third grades. Washington, DC: U.S. Department of Education, Institute of Education Sciences (NCES 2006-099).

Kovalik, S.(1999, February). The body brain connection and learning. Paper presented at the National School Conference Institute's Assessment and instruction: Infusing brain research, multiple intelligences, learning styles, and mind styles, Phoenix, AZ.

Kozol, J.(1992). Savage inequalities: Children in America’s schools. New York: Harper.

Lopez, D.F., Takiff, H., Kernan, T., \& Stone, R. (2000, April). Why art education? Academic implications of art in elementary school. Paper presented at the annual meeting of the American Education Research Association, New Orleans, LA. 
Mandell, J., \& Wolf, J. L. (2003). Acting learning and change: Creating original plays with adolescents. Portsmouth, NH: Heinemann.

Murfee, E. (Ed.). (1997). Priorities for arts education research. Washington, DC: U.S. Government Printing Office, Superintendent of Documents.

National Center for Educational Statistics (IES). (2006, June). Arts instruction of public school students in first and third grade. (Issue Brief No. 099). Washington DC: Author.

Rabkin, N., \& Redmond, R. (2006). The arts make a difference. Alexandria, VA: Association of Supervision and Curriculum Development.

Silver, H.F., \& Hanson, J.R. (1995). Learning styles and strategies. Woodbridge, NJ: Thoughtful Education Press.

Smithrim, K. \& Upitis, R. (2005). Learning through the arts: Lessons of engagement. Canadian Journal of Education 28(1-2), 109-127.

Sousa, D. (2006, December). How the arts develop the young brain.” The School Administrator. 63(11), 26-31.

Stevens, J. (1999). What do educators need to know about the human brain? Unpublished manuscript. Spring Branch Independent School District, Houston.

Stevenson, L. M., \& Deasy, R. J.(2005) Third space: When learning matters. Washington, DC: Arts Education Partnership.

Strauss, V. (2008, February). Relentless question paves a deeper path. The Washington Post. [Electronic Version] Retrieved February 26, 2008 from www.washingtonpost.com Sylwester, R. (1995). A celebration of neurons: An educator's guide to the human brain. Alexandria, VA: Association of Supervision and Curriculum Development. Sylwester, R. (February 24, 2000). Telephone conversation with Judith Witmer. 
Tishman, S., MacGillivray, D., \& Palmer, P. (1999). Investigating the educational impact and potential of the Museum of Modern Art's visual thinking curriculum: Final report. Unpublished report, Museum of Modern Art, New York, NY.

Winner, E., \& Cooper, M. (2000). Mute those claims: No evidence (yet) for a causal link between arts study and academic achievement. [Electronic version]. The Journal of Aesthetic Education, 34(3-4),11-75.

Winner, E., \& Hetland, L. (2000, Fall/Winter). The arts and academic achievement. [Electronic version]. The Journal of Aesthetic Education, 34(3-4), 2-9.

Witmer, J. T. (1996, May). Change the date of band camp? You must be kidding! PMEA News. Pennsylvania Music Educators Association.

Witmer, J. T. (1997a). The keystone integrated framework: A compendium. The Bureau U.S. Dept. of Education, Office of Educational Research and Improvement, Educational Resources Information Center.

Witmer, J. T. (1997b, Fall). What are these keyboards doing here? PMEA News. Pennsylvania Music Educators Association.

Wolfe, P., \& Sorgen, M. (1990). Mind, memory, and learning. Napa, CA: Author.

Wolfe, P., \& Brandt, R. (1998). What do we know from brain research? Educational Leadership, 56(3), 8-13. 